\title{
Transcription factor LSF binds two variant bipartite sites within the SV40 late promoter
}

\author{
Hui-Chuan Huang, Rebecca Sundseth, and Ulla Hansen \\ Laboratory of Eukaryotic Transcription, Dana-Farber Cancer Institute, and Department of Microbiology and Molecular \\ Genetics, Harvard Medical School, Boston, Massachusetts 02115 USA
}

\begin{abstract}
The HeLa transcription factor LSF has been purified by heparin-agarose and DNA affinity chromatography, and its DNA binding and transcription properties have been characterized. LSF is a $63-\mathrm{kD}$ polypeptide that binds to two distinct bipartite sites within the SV40 promoter region. One binding site consists of GC motifs 2 and 3 within the 21-bp repeats (LSF-GC site), and the other consists of sequences centered 44 bp upstream of the major late initiation site, L325 (LSF-280 site). Four guanine residues within the LSF-GC site, when methylated, strongly interfere with LSF binding. Alteration of the spacing, but not the sequence, between the two directly. repeated GC motifs dramatically reduces the binding affinity of LSF for the site. Thus, LSF appears to recognize directly repeated GC motifs, when their center-to-center distance is $10 \mathrm{bp}$. The LSF-GC and LSF-280 sites share limited sequence homology. Only half of the LSF-280 site contains a short GC-rich sequence homologous to the GC motif. However, the binding affinity of LSF to the two sites is similar. LSF activates transcription from the SV40 late promoter in vitro from initiation site L325, via its binding to the template DNA.
\end{abstract}

[Key Words: Transcription factor; DNA-binding protein; SV40 late promoter; GC-motif; LSF; GT-IIA]

Received September 4, 1989; revised version accepted November 29, 1989.

SV40 offers an excellent model system for studying transcriptional regulatory mechanisms in mammalian cells: The virus uses the host cell transcription machinery for expression of its genes, and both biochemical and genetic means can readily be applied in investigating its transcription. During lytic infection, transcription of SV40 is precisely regulated. Before the onset of viral DNA replication, the SV40 early genes (encoding the large-T and small-t antigens) are primarily transcribed; after the onset of viral DNA replication, the SV40 late promoter is activated, and the late genes (encoding the viral capsid proteins) are predominantly expressed (Tooze 1981).

The DNA sequences in the SV40 genome that regulate early and late transcription are located within a region of $\sim 400$ bp (see Fig. 8, below). The SV40 late promoter appears to be very complex and may actually be a combination of multiple overlapping promoters capable of stimulating transcription from the same initiation sites. Many DNA sequence elements have been implicated in promoting late transcription in vivo and/or in vitro. These sequences include the origin of DNA replication (Brady and Khoury 1985; Keller and Alwine 1985), the three 21-bp tandem repeats containing six directly repeated GC motifs (GGGCGG) (Fromm and Berg 1982; Hansen and Sharp 1983; Brady et al. 1984; Hartzell et al. 1984a; Rio and Tjian 1984; Vigneron et al. 1984), the 72-bp direct repeats containing many enhancer elements
(Fromm and Berg 1982; Hartzell et al. 1984b; Keller and Alwine 1985; Emoult-Lange et al. 1987), and the region from the 72-bp repeats up to and beyond the major in vivo initiation site, L325 (Brady et al. 1982; Keller and Alwine 1985; Ernoult-Lange et al. 1987; Ayer and Dynan 1988). The major late initiation site L325 is not preceded by a typical TATA box (Brady et al. 1982). Environmental factors may influence the promoter regions that are important in activating SV40 late transcription. In particular, the presence of $T$ antigen dramatically alters the effect of the GC motif region on the SV40 late promoter, and the occurrence of SV40 DNA replication alters the relative importance of various elements within the 72-bp repeats for SV40 late transcription (Keller and Alwine 1985; Alwine and Picardi 1986; Omilli et al. 1986; Robbins et al. 1986; Ernoult-Lange et al. 1987).

To elucidate the molecular mechanisms of initiation of transcription by RNA polymerase II, the trans-activating factors that interact with cis-activating DNA sequences must be purified. Only then can the interactions of a specific trans-acting factor with the DNA and with other proteins involved in the initiation of transcription at the promoter be studied directly. Multiple DNA-binding proteins specific for sequences within the SV40 promoter region have been identified; however, only recently has the involvement of particular purified proteins in transcription of the major in vivo initiation 
site of the SV40 late promoter been shown. AP-1 and AP-4 were reported to synergistically stimulate SV40 late transcription from the L325 initiation site three- to fourfold in vitro (Mermod et al. 1988). In addition, we identified previously a cellular transcription factor from HeLa cells, LSF (designated late SV40 factor), that stimulated SV40 late transcription and bound specifically sequences within the SV40 21-bp repeat promoter element (Kim et al. 1987). Here, we present the purification and further characterization of LSF. The protein stimulates SV40 late transcription in vitro from the major late initiation site and binds two variant bipartite sites within the SV40 promoter region.

\section{Results}

\section{Purification of LSF}

The LSF purification scheme is described in Methods and summarized in Table 1. HeLa whole-cell extract was applied to a heparin-agarose affinity column, and bound proteins were eluted with a linear salt gradient. Fractions containing LSF demonstrated DNA-binding activities that protected both a sequence including GC motifs 2 and 3 and part of GC-motif 1 (LSF-GC site) and a sequence from nucleotides 272 to 291 (LSF-280 site) from DNase I digestion (Fig. 1B, lanes 3-5, 11). These two regions were distinct from sequences protected from DNase I cleavage by previously identified proteins. [Sp1 binds strongly to GC motifs 3,5 , and 6 within the SV40 21-bp repeats (Gidoni et al. 1984). AP-4 protects only sequences between nucleotides 267 and 276 with high affinity (Mermod et al. 1988).]

To purify further the LSF transcription activity in the heparin eluate, sequence-specific DNA affinity resins were prepared (Kadonaga and Tjian 1986). The first DNA affinity resin contained the SV40 GC motifs 1,2 , and 3 (GC123, nucleotides 42-70), which includes the LSFGC site. After purification by two consecutive passes over the column, the fractions with specific DNAbinding activity (Fig. 1B, lanes 6-9) contained a polypeptide of $63 \mathrm{kD}$ as the major polypeptide species $110 \%$ of the eluted protein), excluding the added carrier protein BSA (Fig. 1A, lane 4). Minor polypeptide species, including those with molecular masses of $105 \mathrm{kD}, 60 \mathrm{kD}$, and $56 \mathrm{kD}$ were also detected in the LSF-containing eluate (lane 4), with all but the $105-\mathrm{kD}$ species also detected in fractions not containing specific DNA-binding activity (e.g., Fig. 1A, lane 3).

Transcriptional analysis of LSF purified by $\mathrm{GCl}_{23}$ DNA affinity chromatography demonstrated SV40 late transcription stimulatory activity (data not shown). However, the fraction also stimulated SV40 early transcription, which was attributed to the presence of $\mathrm{Spl}$ (105-kD minor peptide; Fig. 1A, lane 4; Briggs et al. 1986). Sp1 copurified with LSF on the GC123 DNA column because it binds with high affinity to GC motif 3 (Gidoni et al. 1984). LSF purified by GC123 DNA affinity chromatography was also slightly contaminated with AP-4 (see Fig. 3), which has been reported to stimulate SV40 late transcription (Mermod et al. 1988). To resolve LSF from both Sp1 and AP-4, an alternative DNA affinity resin containing sequences similar to the LSFbinding site within nucleotides $272-291$ was prepared [LSF-280-related site (LSF-280RS) DNA affinity resin]. This sequence had the advantage of containing a high affinity AP-4-binding site and allowed separation of LSF and AP-4.

LSF DNA-binding activity was eluted from the LSF-280RS DNA affinity column entirely within the 0.3 M KCl step (Fig. 1B, lanes 12, 14) and was therefore separated from the AP-4 DNA-binding activity eluting at 0.5 M KCl (Fig. 1B, lane 13; see Mermod et al. 1988). The LSF-containing second pass $0.3 \mathrm{M} \mathrm{KCl}$ eluate was free of all other detectable specific SV40 promoter DNAbinding activities, as assayed both by DNase I footprinting (Fig. 1B, lane 14) and by band mobility-shift analyses (data not shown). Again, this eluate was enriched for a $63-\mathrm{kD}$ protein, which was the most abundant polypeptide in the fractions $(30 \%$ of the eluted protein; Fig. 1A, lane 81.

Both DNA affinity resins, containing different sequences, led to the purification of the $63-\mathrm{kD}$ protein, LSF. Consistent with these data, both preparations of LSF bound to the two sites within the SV40 promoter region (Fig. 1B, lanes 6-9, and 14): GC motifs 2 and 3 (LSF-GC site), and nucleotides 272-291 (LSF-280 site). The binding affinity of LSF to these two sites was similar, as LSF occupied the sites at approximately the same concentration of added protein (Fig. 1B, lanes 6-9; data not shown).

Table 1. Purification of LSF

\begin{tabular}{lccccc}
\hline Fraction & $\begin{array}{l}\text { Total protein } \\
(\mathrm{mg})\end{array}$ & $\begin{array}{l}\text { Activity } \\
\text { (units })^{\mathrm{a}}\end{array}$ & $\begin{array}{l}\text { Specific activity } \\
\text { (U/mg) }\end{array}$ & $\begin{array}{c}\text { Relative purification } \\
\text { (fold) }\end{array}$ & $\begin{array}{c}\text { Yield } \\
(\%)\end{array}$ \\
\hline WCE & 7,500 & 54,500 & 7.3 & -100 \\
Heparin-agarose H2 & 160 & 10,000 & 63 & 8.6 & 18 \\
GC123 DNA affinity II & 0.2 & 6,000 & 30,000 & 3,100 & 11 \\
Heparin-agarose H3 & 99 & 3,300 & 33 & 6.5 \\
LSF-280RS DNA affinity I & 0.7 & 3,100 & 4,400 & 600 \\
LSF-280RS DNA affinity II & 0.07 & $1,700^{\mathrm{b}}$ & $24,000^{\mathrm{b}}$ & $3,300^{\mathrm{b}}$ & $3.1^{\mathrm{b}}$ \\
\hline
\end{tabular}

ane unit of activity is defined as the amount of protein required to provide LSF-GC and LSF-280 sites with $50 \%$ protection against DNase I digestion under standard DNase I footprinting reaction conditions.

betermination done in the presence of carrier poly $[\mathrm{d}(\mathrm{I}-\mathrm{C}) \cdot \mathrm{d}(\mathrm{I}-\mathrm{C})]$ and is therefore a minimum estimate of total units recovered. 


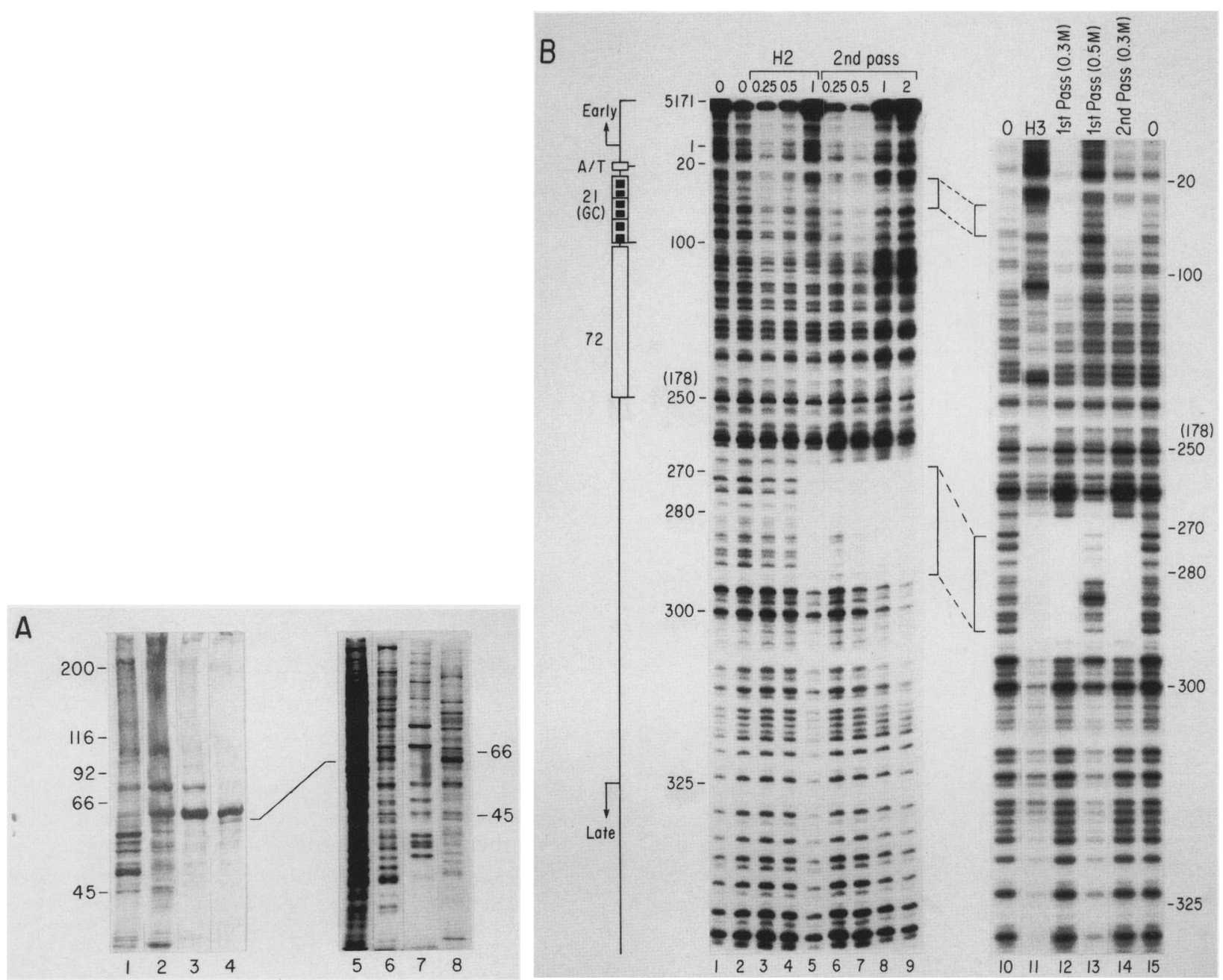

Figure 1. Protein profiles and DNase I footprinting of fractions throughout the LSF purification. (A) SDS-polyacrylamide gel analysis of LSF at various stages of purification, involving GC123 (lanes 1-4) and LSF-280RS (lanes 5-8) DNA affinity chromatography. The following samples were loaded: $4.0 \mu \mathrm{g}(0.25 \mu \mathrm{l})$ of heparin-agarose pool $\mathrm{H} 2$ (lane 1); $0.25 \mu \mathrm{l}$ of the peak fraction from the $0.5 \mathrm{M}$ salt step of the first GC123 pass (lane 2); $4 \mu \mathrm{l}$ of the second GC123 pass flowthrough (lane 3); $0.7 \mu \mathrm{g}(2.5 \mu 1$ ) of the peak fraction from the $0.5 \mathrm{M}$ salt step of the second GC123 pass (lane 4); $11.4 \mu \mathrm{g} \mathrm{H3}$ (lane 5); $0.8 \mu \mathrm{g}$ of the $0.3 \mathrm{M} \mathrm{KCl}$ eluate pool from the first LSF-280RS pass (lane 6); $0.4 \mu \mathrm{g}$ of the peak fraction from the $0.5 \mathrm{M} \mathrm{KCl}$ salt step of the first LSF280RS pass (lane 7); and $0.4 \mu \mathrm{g}$ of the peak fraction of the $0.3 \mathrm{M} \mathrm{KCl}$ salt step from the second LSF-280RS pass (lane 8). Positions of migration of the molecular mass standards in kilodaltons (Bio-Rad) are indicated at left and right. The position of migration of LSF (63 kD) is indicated by the lines between lanes 4 and 5. (B) DNase I footprinting analysis of LSF and other SV40 promoter-binding proteins present in Heparin-agarose pools (lanes 3-5, 11) and GC123 (lanes 6-9) and LSF-280RS (lanes 12-14) DNA affinity chromatographic fractions. DNA fragments of 368 bp (lanes 1-9) and 345 bp (lanes 10-15) were prepared as described in Methods. Binding reactions were assembled as described in Methods with the addition of $0.4 \mu \mathrm{g}$ (lane 3), $0.8 \mu \mathrm{g}$ (lane 4), $1.6 \mu \mathrm{g}$ (lane 5), $0.5 \mu \mathrm{g}$ (lanes 10-13, 15) or $0.2 \mu \mathrm{g}$ (lane 14) of poly[d(I-C) $\cdot \mathrm{d}(\mathrm{I}-\mathrm{C})]$. The following proteins were present in the reactions: no protein added (lanes $1,2,10,15) ; 0.25-1 \mu \mathrm{l} \mathrm{heparin-agarose} \mathrm{pool} \mathrm{H2}(16 \mathrm{mg} / \mathrm{ml}$, lanes 3-5); $0.25-2 \mu \mathrm{l}$ of the peak LSF fraction from the $0.5 \mathrm{M} \mathrm{KCl}$ salt step of the second GC123 pass $(0.14 \mathrm{mg} / \mathrm{ml}, 1 \mathrm{anes} 6-9) ; 21 \mu \mathrm{g}$ $\mathrm{H} 3$ (lane 11); $0.3 \mu \mathrm{g}$ of the LSF pool (0.3 M KCl eluate) from the first LSF-280RS pass (lane 12); $0.3 \mu \mathrm{g}$ of the peak AP-4 fraction from the $0.5 \mathrm{M} \mathrm{KCl}$ salt step of the first LSF-280RS pass (lane 13); $0.09 \mu \mathrm{g}$ of the peak LSF fraction from the $0.3 \mathrm{M} \mathrm{KCl}$ salt step of the second LSF-280RS pass (lane 14). The products were analyzed on a denaturing polyacrylamide gel. The regions protected from DNase I digestion by LSF are indicated by the brackets between lanes 9 and 10. The SV40 nucleotide positions are indicated flanking lanes 1 and 15. (Left) Landmarks within the SV40 promoter region (see legend to Fig. 8).

The DNA binding properties of LSF were also investigated using a band mobility-shift assay. Purified LSF formed one major and two minor protein-DNA complexes with duplex oligonucleotide $\mathrm{GC} 123$ (nucleotides $42-70)$ (Fig. 2). The most abundant complex $(90 \%$ of the
protein-DNA complexes) resulted from a specific protein-DNA interaction, as it was competed by GC123 DNA (lanes 5 and 6), but not by unrelated DNAs (AP-1 DNA or poly[d(I-C) $\cdot \mathrm{d}(\mathrm{I}-\mathrm{C})]$; lanes 7,8 and 3,4 , respectively). 


\section{LSF is a $63-k D$ polypeptide}

To prove that the molecular mass of LSF is $63 \mathrm{kD}$ and to rule out the possibility that purified LSF contains multiple polypeptides that are required for specific DNAbinding activity, the ability of size-fractionated LSF to specifically bind SV40 DNA was tested. A purified preparation of LSF was fractionated on an SDS-polyacrylamide gel, and the proteins from different gel slices were eluted and renatured, as described in Methods. Of proteins corresponding to a wide range of molecular masses, only those within the range of $62-64 \mathrm{kD}$ demonstrated specific binding to the GC123 DNA fragment (Fig. 3A, lane 81 . This proved that the $63-\mathrm{kD}$ polypeptide was necessary and sufficient for formation of the specific LSF/ DNA complex (see Fig. 2).

Protein renatured from the gel slice containing the 63-kD polypeptide also bound to LSF-280 DNA (nucleotides 270-290, cf. Fig. 3A and 3B, lanes 8). In addition, the LSF-280 DNA was bound by smaller polypeptides (Fig. 3B; lanes 11-14); however, the mobilities of these protein-DNA complexes were not identical to that of the LSF-DNA complex (lanes 11-13). The complex in the vicinity of $48 \mathrm{kD}$ was likely to be attributable to the presence of AP-4 (lane 12), as the LSF-280 oligonucleotide contained 7 out of $10 \mathrm{bp}$ of the consensus AP-4binding site (Mermod et al. 1988). To investigate any relation in DNA-binding activity between AP-4 and LSF, the renatured proteins were tested for their ability to bind to a DNA fragment containing only the AP-4binding site. The $63-\mathrm{kD}$ polypeptide, which bound LSF-

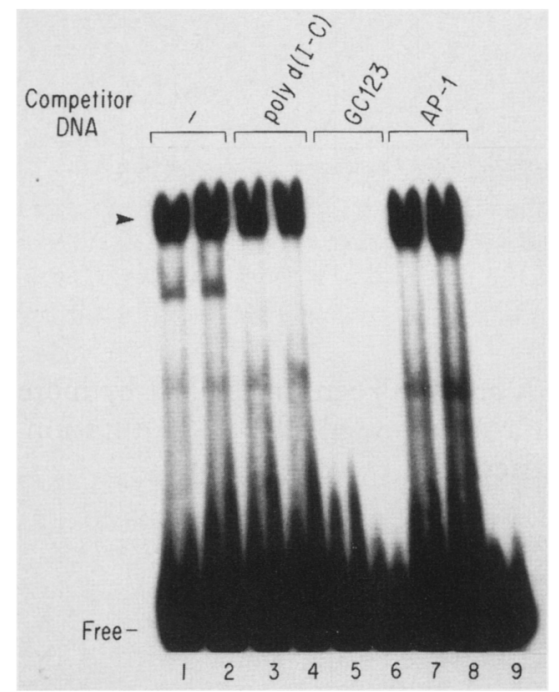

Figure 2. LSF specifically binds sequences within the SV40 21-bp repeats. Band mobility-shift analysis was performed with purified LSF and radiolabeled GC123 DNA. Binding reaction mixtures contained $28 \mathrm{ng}$ of purified LSF and were performed in the presence or absence of unlabeled competitor DNAs, as follows: no competitor DNA (lanes 1 and 2); 25- and 125-fold weight excess, respectively, of poly $[\mathrm{d}(\mathrm{I}-\mathrm{C}) \cdot \mathrm{d}(\mathrm{I}-\mathrm{C})]$ (lanes 3 and 4); 25- and 125-fold molar excess, respectively, of GC123 DNA (lanes 5 and 6); 25- and 125-fold molar excess, respectively, of AP-1 DNA (lanes 7 and 8). (Lane 9) No added protein.

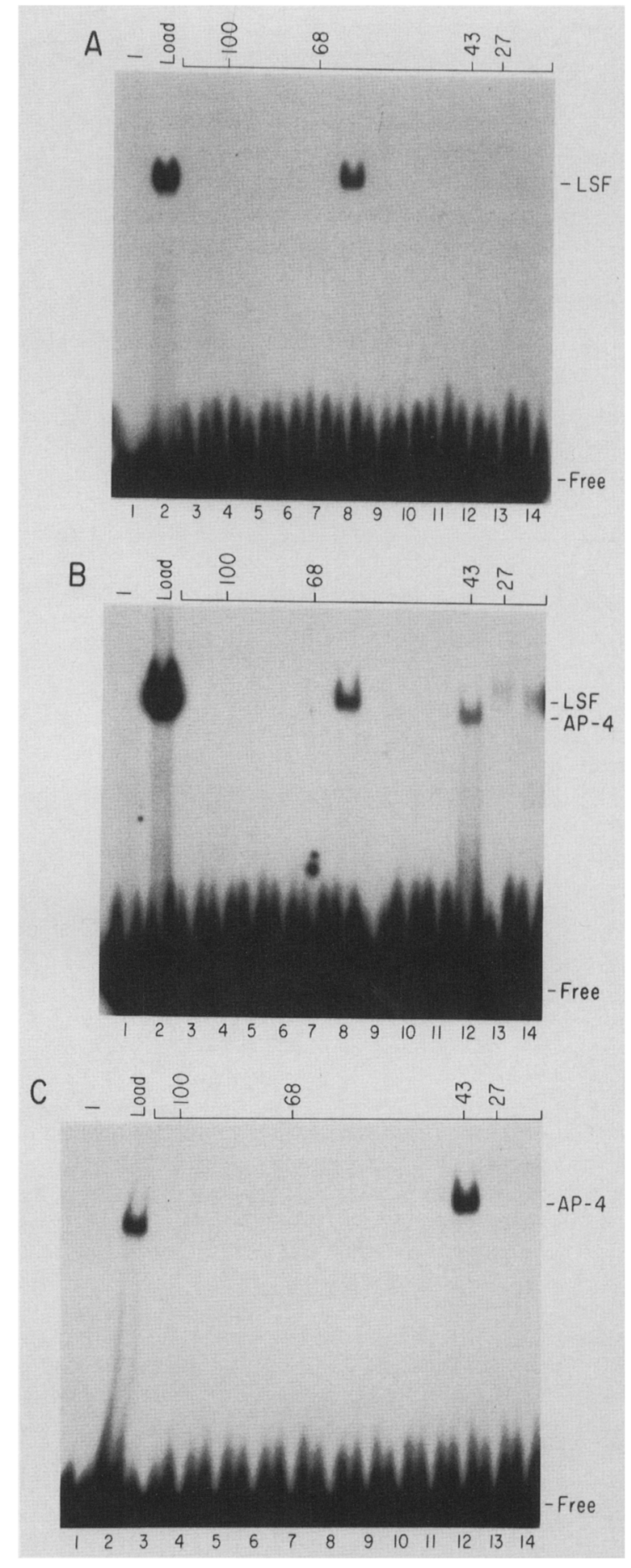

Figure 3. Band mobility-shift assay of proteins renatured from gel slices of an SDS-polyacrylamide gel. Purified LSF was electrophoresed through an SDS-polyacrylamide gel, and proteins from individual gel slices were eluted and renatured (see Methods). Eluate from each gel slice $(12 \mu \mathrm{l}$ from a total of $1 \mathrm{ml})$ was assayed for the ability to bind to $0.4 \mathrm{ng}$ of one of the radiolabeled DNAs (lanes 3-14). Radiolabeled DNAs were GC123 $(A)$, LSF-280 $(B)$, and AP-4 $(C)$. Lanes 1 contained only radiolabeled DNA; lanes 2 contained $14 \mathrm{ng}$ of the purified LSF. Molecular masses (in $\mathrm{kD}$ ) shown above the gels refer to the migration of protein standards relative to the gel slice boundaries. 
GC and LSF-280 DNAs (Fig. 3A,B, lanes 8), did not bind to the AP-4 DNA (Fig. 3C, lane 8). Conversely, the smaller polypeptide AP-4 (Mermod et al. 1988) only bound to the AP-4 and LSF-280 DNAs but not to the GC123 DNA (Fig. 3A-C, lanes 12). Thus, LSF and AP-4 are different proteins with unrelated DNA-binding properties.

\section{$L S F$ binds to two directly repeated GC-motifs at the LSF-GC site}

Methylation interference studies (Siebenlist and Gilbert 1980) were performed to characterize the close contact points made by purified LSF bound to the LSF-GC site. Methylated duplex GC123 DNA was incubated with LSF, and the bound form of DNA was separated from the free form by a band mobility-shift experiment. The methylation patterns of the bound and free DNAs are shown in Figure 4. Although the GC123 DNA was radiolabeled at both $5^{\prime}$ termini, radioactive fragments cleaved at all individual guanine residues from both DNA strands were uniquely separated following electrophoresis through a denaturing polyacrylamide gel (Fig. 4, lanes 4 and 5). Formation of the LSF complex was strongly inhibited by methylation of four guanine residues, located at positions $53,58,63$, and 68 , as bound DNA did not contain methylated bases at these positions (cf. lane 2 with lanes 1 and 3). These four guanine residues represent two from each GC motif, at equivalent positions (solid arrows within the LSF-GC site in Fig. 8). In addition, methylation of guanine residues at positions 54,57, and 64 partially inhibited LSF binding (shaded arrows within the LSF-GC site in Fig. 8). The fact that $\mathrm{N} 7$ methylation of guanine residues inhibited binding of LSF suggests that LSF binds within the major groove of the DNA.

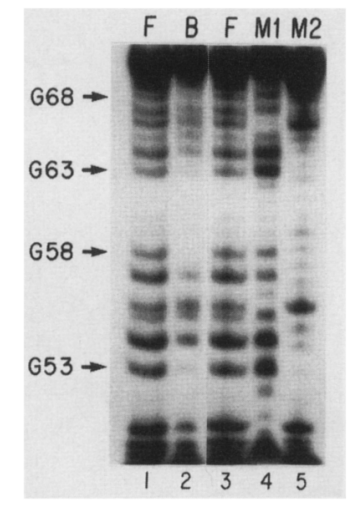

Figure 4. Methylation interference analysis of contacts between GC123 DNA and LSF. Partially methylated, radiolabeled DNA was incubated with LSF, and the mixture electrophoresed through a nondenaturing gel (see Fig. 2). The methylation pattern of the DNA bound to protein (lane 2, B) was compared with the methylation pattern of the GC123 DNA (lanes 1, 3; F). The GC123 DNA was radiolabeled at both 5 ' termini. Guanine ladders of the upper and lower strands of the DNA (see Fig. 8) are shown in lanes 4 and 5 ( $\mathrm{Ml}$ and M2), respectively. Arrows indicate residues that, when methylated, strongly prevent formation of the LSF/GC123 DNA complex.

\section{LSF-GC binding site is bipartite}

To characterize further the sequence requirements for binding of LSF to the LSF-GC site, the ability of LSF to bind several duplex mutant oligonucleotides (sequences shown in Fig. 5B) was tested. The mutant DNAs were used as competitors for the binding of purified LSF to wild-type DNA, using the band mobility-shift assay. On the basis of the methylation interference results, a smaller oligonucleotide representing the wild-type LSFGC site (LSF-GC DNA, nucleotides 51-70, Fig. 5B) was synthesized and used for the band mobility-shift assay. The binding affinity of LSF to LSF-GC DNA was comparable to that of LSF to GC123 DNA (data not shown).

Four mutants were analyzed: The 4 bp between GC motifs 2 and 3 was altered in m-Mid; 3 bp within GC motif 2 or 3 was altered in $\mathrm{m}-2$ and $\mathrm{m}-3$, respectively; and $4 \mathrm{bp}$ was inserted between GC motifs 2 and 3 in $\mathrm{m}$-Ins (Fig. 5B). [Note that $\mathrm{m}-\mathrm{Mid}, \mathrm{m}$-Ins, and $\mathrm{m}-2$ should all mutate the potential AP-4-binding site at nucleotides 55-64 within this region, whereas $\mathrm{m}-3$ should not (Mermod et al. 1988).) With these mutants, the requirement for specific DNA sequences at three different positions within the LSF-GC site, as well as for particular spacing between different portions of the site, could be determined. The complex formed between LSF and wild-type LSF-GC DNA, in the absence of competitor DNA, is shown in Figure 5A, lanes 1 and 14. As expected, at 10 - or 100-fold molar excess, the LSF-GC DNA effectively competed for LSF binding to radiolabeled LSF-GC DNA (lanes 4 and 5), whereas the control competitor DNA containing the unrelated AP-1 sequence did not compete at all (lanes 2 and 3). The m-Mid DNA also competed well, although with an apparent 10fold lower affinity than the wild-type LSF-GC DNA (lanes 6 and 7). In contrast, the two mutant DNAs $\mathrm{m}-2$ and $\mathrm{m}-3$ (lanes 10-13) competed poorly for binding of LSF to the wild-type LSF-GC site (with an apparent affinity of at least 100-fold lower than that of LSF-GC DNA). The requirement for specific DNA sequences within either GC motif was therefore more stringent than the requirement for specific DNA sequences between the motifs. As was suggested by the results shown in Figure $5 \mathrm{~A}$ and has been made clear by more detailed studies (data not shown), the m-2 mutation was the most detrimental mutation for binding of LSF to the LSF-GC site.

As with the m-2 and m-3 mutant DNAs, m-Ins DNA competed poorly (lanes 8 and 9). These results, taken together, demonstrate that LSF recognizes two half-sites at its LSF-GC-binding site and that these half-sites must be positioned at a specific distance to bind with high affinity to LSF.

The binding affinities of LSF to its two distinct binding sites are similar

To examine further the relative affinities of LSF to the LSF-GC- and LSF-280-binding sites and to determine whether each site could compete for binding to the other site, competition analyses, using the band mobility-shift 

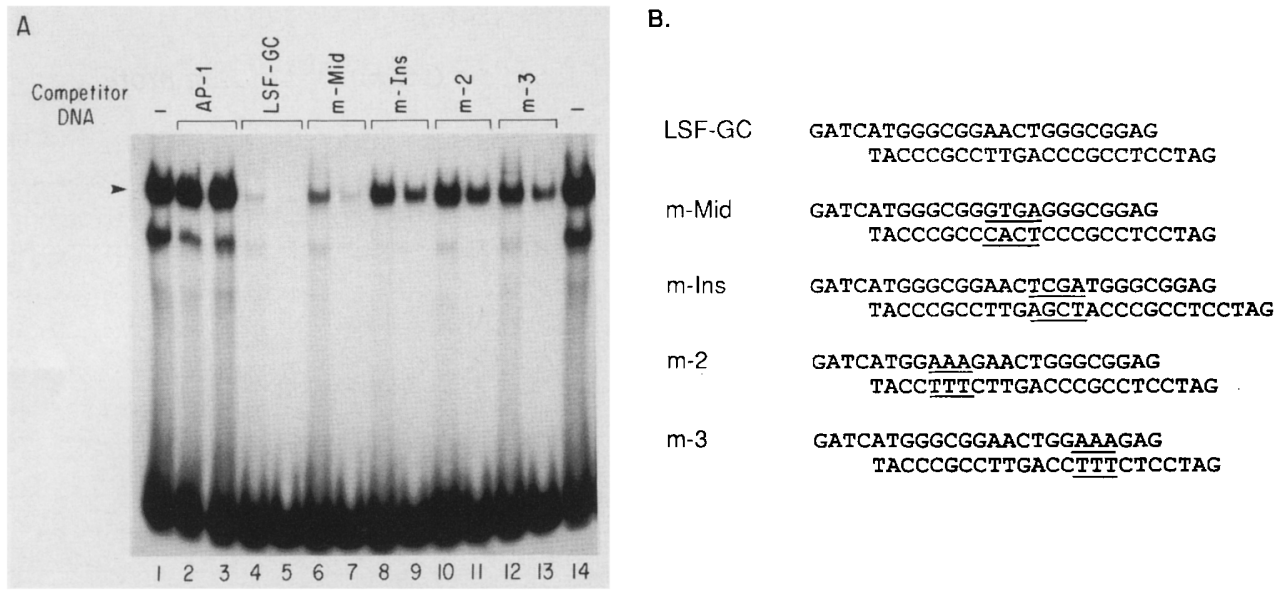

Figure 5. Effects of various LSF-GC site mutations on the relative binding affinity of LSF to the site. $(A)$ Band mobility-shift analysis of the interaction between purified LSF and wild-type radiolabeled LSF-GC DNA in the absence and presence of unlabeled competitor DNAs. Competitor DNAs used were AP-1 (lanes 2 and 3), wild-type LSF-GC (lanes 4 and 5), m-Mid (lanes 6 and 7), m-Ins (lanes 8 and 9), m-2 (lanes 10 and 11), and m-3 (lanes 12 and 13). Competitor DNAs were present at a 10-fold (even lanes) or a 100-fold (odd lanes) molar excess over the radiolabeled DNA. No competitor DNA was present for lanes 1 and 14. (B) Nucleotide sequences of the mutant synthetic DNAs. LSF-GC is the wild-type sequence. Underlines indicate the altered base pairs in the mutants $\mathrm{m}$-Mid, $\mathrm{m}$-Ins, $\mathrm{m}$-2, and $\mathrm{m}-3$.

assay, were performed. Unlabeled LSF-GC DNA, added at a fivefold molar excess, efficiently competed for LSF binding to both LSF-GC and LSF-280 radiolabeled DNAs (Fig. 6, lanes 3, 4, 10, and 11). Reciprocally, unlabeled LSF-280 DNA, added at a fivefold molar excess, also efficiently competed for LSF binding to both LSF-GC and LSF-280 radiolabeled DNAs (Fig. 6, lanes 7, 8, 14, and

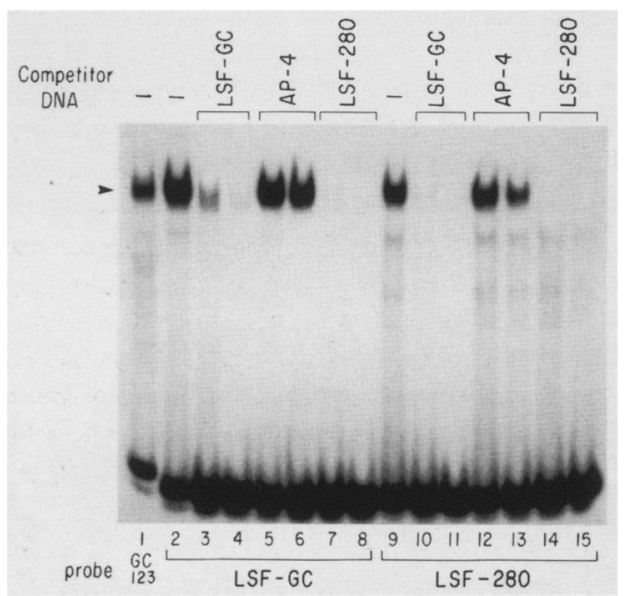

Figure 6. LSF binds to the LSF-GC- and LSF-280-binding sites with similar affinity. The formation of the specific proteinDNA complex between LSF and either radiolabeled LSF-GC DNA (lanes 2-8) or radiolabeled LSF-280 DNA (lanes 9-15) was analyzed in the presence and absence of competitor DNAs. Reactions displayed in lanes 2 and 9 contained no competitor DNA. Competitor DNAs used in the other reactions were LSFGC (lanes 3, 4, 10, and 11), AP-4 (lanes 5, 6, 12, and 13), and LSF-280 (lanes 7, 8, 14, and 15). Competitor DNAs were present at a 5-fold molar excess (lanes $3,5,7,10,12$, and 14) or a 50-fold molar excess (lanes 4, 6, 8, 11, 13, and 15) over the radiolabeled DNAs. Lane 1 contained radiolabeled GC123 DNA plus purified LSF.
15). However, the duplex oligonucleotide containing the consensus AP-4-binding site did not compete for LSF binding to either LSF-GC or LSF-280 DNA (lanes 5, 6, 12 , and 13), which is consistent with the inability of the renatured $63-\mathrm{kD}$ protein to bind radiolabeled AP-4 DNA (see Fig. 3C). Thus, these results indicate that each site could compete for LSF binding to the other site and that the affinities of LSF for LSF-GC DNA and LSF-280 DNA were similar (consistent with DNase I footprinting experiments; Fig. 1B, lanes 6-9). The similar affinities of LSF binding to the LSF-GC and LSF-280 sites was quite surprising, as the two LSF binding sites are not identical (see Fig. 8, below; Discussion).

\section{Transcriptional activation by LSF in vitro}

To test for the ability of LSF to activate SV40 transcription, the LSF preparation devoid of Sp1, AP-4, and all other known SV40-specific DNA-binding proteins (Fig. $1 B$, lane 14) was assayed in a reconstituted in vitro transcription system (Fig. 7; Samuels et al. 1982; Reinberg and Roeder 1987; Reinberg et al. 1987). The assay included the adenovirus major late promoter (Ad MLP) as an internal control. In the absence of added LSF, the reconstituted system initiated transcription at the $\mathrm{Ad}$ MLP much more efficiently than at the SV40 late start site L325 (SV L325; Fig. 7, lane 1). The basal level of transcription from SV L325 was attributable, in part, to the presence of LSF in the reconstituted system /data not shown). However, on the addition of highly purified LSF, the efficiency of initiation of transcription at SV L325 increased approximately fivefold relative to that of the Ad MLP control (lane 2). In contrast, the transcriptional effect of LSF on the SV40 early-early promoter was variable and slight (less than twofold relative to the Ad MLP; data not shown). 


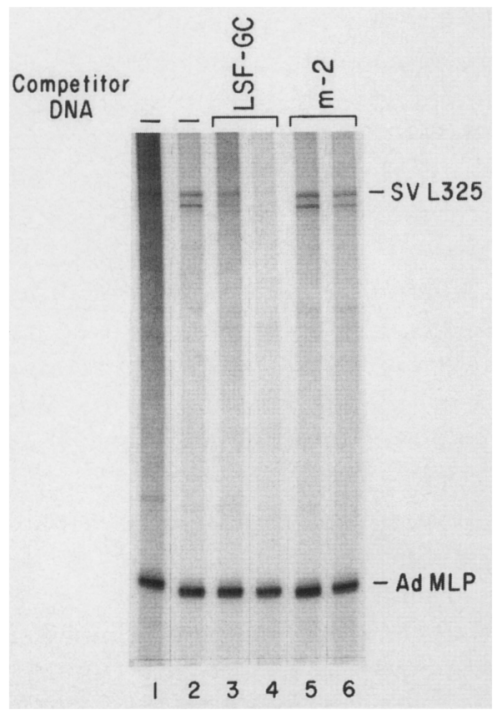

Figure 7. Analysis of LSF transcriptional activity on SV40 (SV L325) and adenovirus (Ad MLP) late promoters in a reconstituted in vitro transcription system. General RNA polymerase II transcription factors were combined, as described in Methods, in the absence (lane 1), or presence (lanes 2-6) of $200 \mathrm{ng}$ LSF. This mixture was incubated in the absence (lanes 1 and 2), or presence (lanes 3-6) of competitor DNAs prior to addition of template DNAs. Competitor DNAs used were LSF-GC DNA (30 ng, lane 3; $300 \mathrm{ng}$, lane 4) and m-2 DNA (30 ng, lane 5; 300 ng, lane 6). Radiolabeled RNAs synthesized in the transcription reaction were selected by hybridization and resolved by electrophoresis through the denaturing polyacrylamide gel shown. The migration positions of RNAs initiated at SV L 325 and Ad MLP are indicated. The $5^{\prime}$ terminus of the RNA product migrating slightly faster than the SV L325 RNA has been mapped to 18-20 bp downstream of SV L325 (nucleotides 353-355). SV40 $16 \mathrm{~S}$ mRNAs with initiation sites around this position have been observed in vivo when deletions are present in the late leader region, either downstream or upstream of the late initiation sites (Piatak et al. 1981, 1983).

To prove that the transcriptional stimulation of the SV40 late promoter was attributable to the specific binding of LSF to the template DNA, competitor DNAs were added during the transcription reaction. At a 10fold molar excess of LSF-GC DNA over LSF-binding sites in the SV40 viral DNA transcription template (lane 3), the activation by LSF at SV L325 was decreased 4-fold (cf. lanes 2 and 3), and at 100-fold molar excess, the SV40 L325 signal was decreased 9-fold (cf. lanes 2 and 4). The competitor DNA clearly competed away both the added LSF and the endogenous LSF in the reconstituted transcription reaction. In contrast, $\mathrm{m}-2$ DNA had no effect when added at either 10- or 100-fold molar excess (lanes 5,6 , respectively).

These results demonstrate that the $63-\mathrm{kD}$ site-specific DNA binding protein LSF is a transcription factor that activates the SV40 late promoter at the major late mRNA start site observed in vivo, L325. In addition, the competition data show that the specific binding of LSF to the transcription template is absolutely required for its transcriptional stimulatory activity.

\section{Discussion}

\section{LSF is a GC motif-binding protein}

Two GC motif-binding proteins have been characterized previously; Sp1 and MTF-1 (Gidoni et al. 1984; Westin and Schaffner 1988). Spl binds to GC-motifs in many viral and cellular genes (Dynan 1986; Kadonaga et al. 1986). MTF-1, a zinc-inducible factor, binds to the mouse methallothionein I gene (at the MREd site; Westin and Schaffner 1988). LSF is different from both Sp1 and MTF-1 by virtue of its DNA binding properties and its molecular mass. Of six GC motifs in the SV40 promoter, LSF only binds strongly to GC motifs 2 and 3 , whereas Spl binds strongly to GC motifs 3, 5, and 6 (Gidoni et al. 1984). The methylation of guanine residues located at the boundaries of each GC-motif (GGGCGG) strongly interferes with binding of LSF to the DNA. In contrast, guanine residues, both at the boundaries and in the center of the GC motifs, are involved as closed contact points for binding of Spl to both SV40 and the MREd sites (GGGCGG and GGGCGG, respectively;

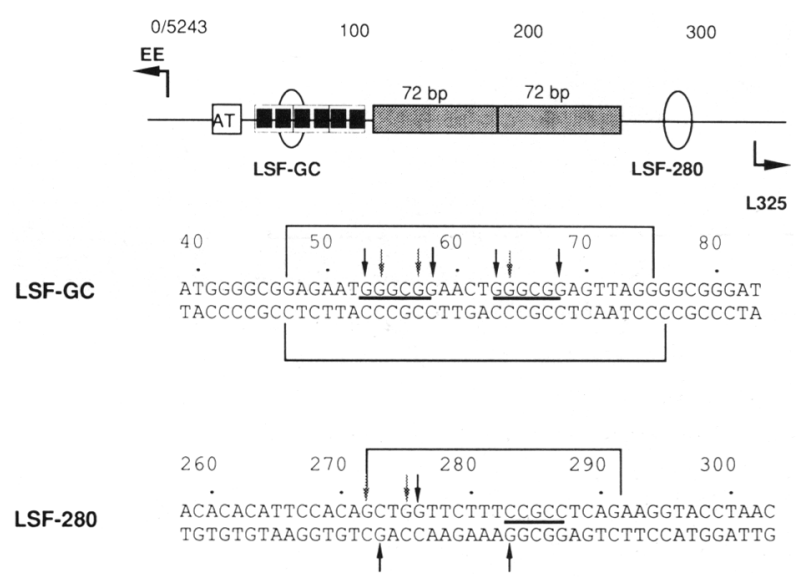

Figure 8. Summary of DNase I protection and methylation interference analyses of the LSF complexes at LSF-GC and LSF-280 DNA sites within the SV40 promoter region. (Top) Map of the SV40 late and early promoter region. The numbers of nucleotide positions are given above the map. The indicated landmarks of the promoter region include: two 72 -bp repeats (shaded boxes), six directly repeated GC motifs (solid boxes) within three copies of direct 21 -bp repeats (open boxes), a stretch of 17 adenine and thymine base pairs, including the early TATA sequence (AT box), SV40 early-early and major late initiation sites (EE and L325, respectively), and the two LSF DNA-binding sites (LSF-GC and LSF-280). DNA sequences containing the LSF-GC- and LSF-280-binding sites are represented below. Brackets mark the overall limits of the DNase I-protected regions by LSF at both LSF-GC and LSF- 280 sites. The brackets indicate a minimal protection region, as the boundaries were determined by the outermost cleavage sites protected, and the next unaffected DNase cleavage sites were not at adjacent base pairs. The solid and shaded arrows in the sequence diagram of LSF-GC highlight residues that, when methylated, strongly or partially prevent LSF binding, respectively. The solid and shaded arrows in the sequence diagram of LSF-280 indicate residues that, when methylated, strongly or partially prevent GT-IIA binding (Xiao et al. 1987). 
Gidoni et al. 1984; Westin and Schaffner 1988) and for binding of MTF-1 to the MREd site (GGGCGG; Westin and Schaffner 1988). Furthermore, the apparent molecular mass of LSF is $63 \mathrm{kD}$, whereas Spl is $95 / 105 \mathrm{kD}$. The molecular mass of MTF-1 is as yet undetermined.) Taken together, the data indicate that LSF is a novel GC motif-binding protein.

\section{The LSF-GC binding site contains directly repeated} half-sites

Of the six tandem GC motifs (GGGCGG) in the SV40 DNA, LSF binds with high affinity to the GC-motif 2 and 3 pair. The distance between the centers of pairs of GC motifs within the SV40 promoter varies from 9 to 12 bp. Only GC motifs 2 and 3 are spaced $10 \mathrm{bp}$ apart. The importance of this spacing for high-affinity LSF binding was shown by inserting 4 bp between GC motifs 2 and 3 (m-Ins); this mutant dramatically decreased the binding of LSF to the DNA. These data, combined with the evidence that the sequences recognized within the LSF-GC site are indeed the GC motifs (see Fig. 5), suggest that LSF interacts with two identical half-sites that must be spaced precisely for optimal binding.

Many DNA-binding proteins consist of oligomeric structures comprised of identical subunits. In most cases, the DNA sequences with which these proteins specifically interact correspondingly contain a region of dyad symmetry (e.g., $\lambda$ repressor; Pabo and Sauer 1984). Only a few proteins have been shown to bind as oligomeric structures to directly repeated elements, such as the $\lambda$ cII-positive regulator protein, which forms a tetramer in solution that interacts with two directly repeated sequences (Ho et al. 1982). We have shown that LSF binds to directly repeated GC motifs, and preliminary data suggest that LSF exists in the same form when free in solution as when bound to DNA. LSF migrated with the same mobility when electrophoresed through native polyacrylamide gels either in the absence or the presence of small DNA fragments $(20 \mathrm{bp})$ containing the LSF-GC binding site (H.-C. Huang, unpubl.). Therefore, LSF either oligomerizes prior to binding to the DNA or it contains two DNA-binding domains within a single 63-kD polypeptide.

\section{LSF binds with similar affinities to two different sequences}

In contrast to the LSF-GC site, the LSF-280-binding site does not consist of an obvious directly repeated sequence (Fig. 8). The fact that LSF-GC and LSF-280 sites cross-competed for binding to LSF in the band mobilityshift experiments indicates, however, that both DNA sites are recognized by the same, or overlapping, regions on the protein. In addition, several observations argue against the possibility that there are two different modified forms of LSF, each of which binds preferentially to one of the LSF-GC- or LSF-280-binding sites. The LSF preparations resulting from purification over two dif- ferent DNA affinity resins, each representing one of the LSF-binding sites, yielded the same DNase I footprints (Fig. 1B) and band mobility-shifts (data not shown). Furthermore, when titrated on SV40 promoter DNA, both preparations occupied the LSF-GC and LSF-280 sites to similar extents at all levels of added protein (Fig. 1B; data not shown). The DNA sequences of the LSF-GCand LSF-280-binding sites are quite different (Fig. 8). Only half of the LSF-280-binding site contains sequence homology to a GC motif, at a position comparable to that of GC motif 2 within the LSF-GC site. Within the LSFGC and LSF-280 GC motif half-sites, there is an identical 7-bp stretch (nucleotides 54-60; nucleotides 287-281), whereas the other half-sites (GC motif 3, nucleotides $62-70$, versus nucleotides 280-272) contain only an identical 2 out of $10 \mathrm{bp}$. However, we can readily conclude that the recognition of LSF for its binding sites does not solely consist of a single GC motif and adjacent $10 \mathrm{bp}$ of any other sequence, because LSF does not bind with high affinity to GC motifs in the SV40 21-bp repeat region other than the GC motif $2 / 3$ pair. Four other GC motifs, along with their adjacent $10 \mathrm{bp}$ of DNA, are available on the wild-type SV40 promoter, yet LSF binding to these sites is undetectable by DNase I footprinting assays.

To compare the detailed interaction of LSF at its two binding sites, one can compare the methylation interference patterns generated by LSF binding these two DNAs (Fig. 8). GT-IIA, a protein identified within crude cellular extracts, binds nucleotides 271-284 within the SV40 promoter (Xiao et al. 1987) and probably represents the same protein as LSF. The methylation interference pattern of GT-IIA at the LSF-280 site (Fig. 8) is identical to the methylation interference pattern of LSF at a highly homologous cellular-binding site /data not shown). There are intriguing similarities between the two binding sites in the positions of guanine residues assumed to be important for close contacts with LSF. The guanine residue at nucleotides 283 in the GC motif within the LSF-280 site and the guanine residue 10 -bp away at nucleotides 273 correspond to G58 and G68 of the LSF-GC site, respectively. The G53 and G63 residue contact points are replaced by adenine residues in the LSF-280 site and, therefore, cannot be compared. However, considerably more data are required concerning the detailed binding of LSF to both sites before it can be determined whether the protein contacts both sites similarly.

One aspect of the sequence at the LSF-280 site suggests a model of how LSF could interact specifically with similar affinities to the two different DNA sequences. In the middle of the LSF- 280 site, there are three consecutive adenine residues on one strand, a sequence sufficient to allow bending of the DNA (Travers 1989). Thus, it is possible that LSF interacts with the LSF-280 GC motif in a way similar to the way it does with GC motif 2 ; and with bending of the DNA at the LSF-280 site, a different surface of the DNA is presented to the second LSF DNA-binding surface, allowing for specific interaction with a distinct DNA sequence. 
DNA-binding proteins capable of binding different DNA sequences that share little sequence homology have recently been described (for review, see Johnson and McKnight 1989): TEF-1 from HeLa cells, C/EBP from rat liver, and HAP1 from yeast. The significance of such different binding sites with comparable DNA binding affinities is still unclear. In the case of LSF, one DNA sequence may mediate repression of transcription, whereas the other may mediate activation of transcription, as has been proposed for different specific DNAbinding sites within different promoters that bind the glucocorticoid receptor /see Johnson and McKnight 1989).

\section{LSF stimulates SV40 late transcription}

Mutational analyses of the SV40 late promoter, both in vitro and in vivo, have demonstrated the importance of DNA sequences around both the LSF-GC- and the LSF-280-binding sites for efficient transcription from the L325 initiation site. Deletion of sequences that include the LSF-GC site within the 21-bp repeats can result in a 3- to 10-fold decrease in late promoter function in vivo (Fromm and Berg 1982; Hartzell et al. 1984a; Chalifour et al. 1987; Ernoult-Lange et al. 1987; Hertz and Mertz 1988), and similar mutants demonstrate a 2- to 10-fold dependence of SV40 late promoter activity on the GC motif-containing 21-bp repeats in vitro (Hansen and Sharp 1983; Brady et al. 1984; Rio and Tjian 1984; Vigneron et al. 1984). Deletion of sequences within or overlapping the LSF-280 site or multiple point mutations within the site decrease transcription from L325 at least two- to fivefold, both in vivo and in vitro /Keller and Alwine 1985; Ernoult-Lange et al. 1987; Ayer and Dynan 1988). Consistent with these previous observations is the ability of LSF, shown here, to stimulate transcription from L325 5- to 9-fold in a reconstituted in vitro system (Fig. 7). Previously, we reported that crude protein preparations of LSF also stimulated transcription from L264 and LE (Kim et al. 1987), but this was a result of a contaminating transcription factor (R. Sundseth, unpubl.).

Other proteins have been reported to stimulate SV40 late transcription in vitro. AP-1 and AP-4 apparently act in concert to activate SV40 late transcription in vitro through binding to sites at positions 256-262 and 267-276, respectively (Mermod et al. 1988). This binding site for AP-4, as well as a low affinity AP-4-binding site within the 21-bp repeats, overlaps with the two LSFbinding sites (LSF-280 and LSF-GC, respectively). However, LSF is clearly different from AP-4 in terms of molecular mass (Fig. 3), chromatographic properties (Fig. 1B), and specificities of binding to DNA (Fig. 3). The functional significance of the overlapping binding sites of AP-4 and LSF remains unclear. Different factors recognizing overlapping or adjacent DNA sequences may interact or compete with each other to produce synergistic or inhibitory effects.

Finally, an impure transcription activity, the late promoter activating factor (LAF), binds the SV40 promoter region (nucleotides 240-300) and also stimulates transcription from the SV40 late promoter in vitro (Beard and Bruggmann 1988). The LSF-binding site LSF- 280 is contained within the site protected from DNase I cleavage by LAF. Thus, LSF may be one of the active components within the LAF fraction.

The DNA-binding and transcription properties of LSF suggest that it could be involved in the temporal regulation of the SV40 early and late promoters. Spl binding to GC motifs 1, 2, and 3 is most important for mediating its activation of the SV40 early promoter (Barrera-Saldana et al. 1985; Gidoni et al. 1985). The overlap between the LSF-GC-binding site and two of these functional Spl-binding sites suggests that the two proteins may compete for binding within the SV40 promoter. Such competition may be involved in regulating the switch from early to late transcription during an SV40 lytic infection.

\section{Methods}

\section{Purification of LSF}

Suspension cultures of HeLa S-3 cells lobtained from the Massachusetts Institute of Technology Cell Culture Facility) were harvested at logarithmic growth phase $\left(4 \times 10^{5}\right.$ to $6 \times 10^{5}$ cells $/ \mathrm{ml})$. Whole-cell extracts were prepared essentially as described (Manley et al. 1980) from 180-190 grams of HeLa cells. Whole-cell extract $(230 \mathrm{ml})$ in buffer A $[50 \mathrm{mM}$ HEPES $(\mathrm{pH}$ 7.9 |, $12.5 \mathrm{mM} \mathrm{MgCl} 2,1 \mathrm{~mm}$ ethylenediaminetetraacetic acid (EDTA), 17\% glycerol, $1 \mathrm{mM}$ dithiothreitol (DTT)] with $0.1 \mathrm{M}$ $\mathrm{KCl}$ was loaded onto an 80-ml DEAE-Sepharose (Pharmacia) column to remove nucleic acids. The flowthrough fractions of the DEAE-Sepharose column were loaded onto a $150 \mathrm{ml}$ heparin-agarose (LKB: Heparin-Ultrogel) column. Proteins were eluted with a 1-liter linear salt gradient (from $0.1 \mathrm{M}$ to $1.0 \mathrm{M}$ $\mathrm{KCl}$ ) in buffer $\mathrm{A}$. The fractions were pooled from $0.17-0.24 \mathrm{M}$ and $0.24-0.28 \mathrm{M} \mathrm{KCl}$ for $\mathrm{H} 2$ and $\mathrm{H} 3$ pools, respectively, and proteins precipitated with ammonium sulfate, resuspended in

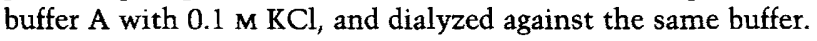
GC123 DNA: CATGGGGCGGAGAATGGGCGGAACTGGGCGGAGC CCCGCCTCTTACCCGCCTTGACCCGCCTCGGTAC

spanning nucleotides $38-70$ at the SV40 promoter region, and

LSF-280RS DNA: GATCAGCTGCAGCCCGC TCGACGTCGGGCGCTAG

spanning -74 to -88 of the human proenkephalin promoter and including an AP-4-binding site (Comb et al. 1988), were oligomerized to prepare DNA affinity resins, as described (Kadonaga and Tjian 1986). Heparin-agarose pool $\mathrm{H} 2(16 \mathrm{mg} / \mathrm{ml})$ was dialyzed against buffer B [25 mM HEPES (pH 7.9), $5 \mathrm{~mm}$ $\mathrm{MgCl}_{2}, 0.4 \mathrm{mM}$ EDTA, $0.1 \% \mathrm{NP}-40,17 \%$ glycerol, and $1 \mathrm{mM}$ DTT] plus $0.1 \mathrm{M} \mathrm{KCl}$, and poly[d(I-C) $\cdot \mathrm{d}(\mathrm{I}-\mathrm{C})]$ (BoehringerMannheim) was added as carrier nucleic acid to a final concentration of $62.5 \mu \mathrm{g} / \mathrm{ml}$. The sample was incubated with $1.7 \mathrm{ml}$ of GC123 DNA affinity resin for $16 \mathrm{hr}$ at $4^{\circ} \mathrm{C}$. The resin was packed into a column and washed with buffer B containing 0.1 $\mathrm{M} \mathrm{KCl}$ and $200 \mu \mathrm{g} / \mathrm{ml} \mathrm{BSA}$. Proteins bound to the resin were successively eluted with buffer $B$ containing $0.5 \mathrm{M} \mathrm{KCl}$ and 200 $\mu \mathrm{g} / \mathrm{ml} \mathrm{BSA}$ and buffer B plus $1.0 \mathrm{M} \mathrm{KCl}$ plus BSA. Peak fractions from the $0.5 \mathrm{M} \mathrm{KCl}$ eluate (Fig. 1A, lane 2), which contained LSF DNA-binding activity, were pooled and diluted to $0.1 \mathrm{M} \mathrm{KCl}$. Poly $[\mathrm{d}(\mathrm{I}-\mathrm{C}) \cdot \mathrm{d}(\mathrm{I}-\mathrm{C})]$ was added to $2 \mu \mathrm{g} / \mathrm{ml}$, and the sample was applied to a $0.8-\mathrm{ml} \mathrm{GC123}$ DNA affinity column. The second column was eluted as before. 
Heparin-agarose pool $\mathrm{H} 3(99 \mathrm{mg})$ was diluted in an appropriate buffer to give the following final concentrations: 5.7 $\mathrm{mg} / \mathrm{ml}$ protein, $20 \mathrm{~mm}$ HEPES ( $\mathrm{pH} 7.8$ ), $80 \mathrm{~mm} \mathrm{KCl}, 4 \mathrm{~mm}$ $\mathrm{MgCl}_{2}, 10 \%$ glycerol, $0.1 \mathrm{~mm}$ EDTA, and $1 \mathrm{~mm}$ DTT. Poly[d(IC) $\cdot \mathrm{d}(\mathrm{I}-\mathrm{C})]$ carrier DNA was added to $15 \mu \mathrm{g} / \mathrm{ml}$, and the sample was then incubated at $0^{\circ} \mathrm{C}$ for $15 \mathrm{~min}$, cleared of insoluble material, and applied to a 1.2-ml LSF-280RS DNA affinity resin equilibrated in buffer $\mathrm{C}$ [ $20 \mathrm{mM}$ HEPES $(\mathrm{pH} 7.8), 4 \mathrm{~mm} \mathrm{MgCl}_{2}$, $0.1 \mathrm{~mm}$ EDTA, $10 \%$ glycerol, $1 \mathrm{mM}$ DTT, $0.1 \%$ NP-40] containing $0.08 \mathrm{M} \mathrm{KCl}$. The resin was successively eluted (at 2 $\mathrm{ml} / \mathrm{hr}$ ) with buffer C plus $0.3 \mathrm{M} \mathrm{KCl}$ plus $100 \mu \mathrm{g} / \mathrm{ml}$ insulin and buffer C plus $0.5 \mathrm{M} \mathrm{KCl}$ and $100 \mu \mathrm{g} / \mathrm{ml}$ insulin. The $0.3 \mathrm{M} \mathrm{KCl}$ eluate containing LSF DNA-binding activity was diluted to 0.1 M KCl, poly[d(I-C) $\cdot \mathrm{d}(\mathrm{I}-\mathrm{C})]$ added to $1 \mu \mathrm{g} / \mathrm{ml}$, and the protein applied to a $0.4-\mathrm{ml}$ LSF-280RS DNA resin. The second column was eluted as before.

\section{Analysis of protein}

The protein concentrations for HeLa whole-cell extract, $\mathrm{H} 2$, and H3 were measured as described (Bradford 1976). Protein concentrations of DNA affinity chromatographic fractions were measured by comparison with BSA standards and other proteins of known concentration, following SDS-PAGE through discontinuous $7.5 \%$ or $10 \%$ polyacrylamide gels (Laemmli 1970). Silver staining of the proteins within the polyacrylamide gels was performed as described (Wray et al. 1981). For quantitation, a photographic negative was made of the stained gel and the relative peak areas of different bands determined by scanning with an LKB Ultroscan II scanning densitometer.

\section{Renaturation of gel-purified LSF}

Renaturation of protein from a preparative SDS-polyacrylamide gel was performed as described (Hager and Burgess 1980). LSF purified by GC123 DNA chromatography (11.2 $\mu$ g total protein) was electrophoresed through a $7.5 \%$ SDS-polyacrylamide gel. Prestained protein molecular mass standards (BRL, 14.3-200 $\mathrm{kD}$ / were electrophoresed in lanes adjacent to the LSF sample. Gel slices were cut at 6- to $10-\mathrm{mm}$ intervals and the proteins eluted overnight at $22^{\circ} \mathrm{C}$ into $50 \mathrm{~mm}$ Tris $(\mathrm{pH} 7.9), 0.1 \mathrm{~mm}$ EDTA, $0.1 \%$ SDS, $5 \mathrm{~mm}$ DTT, $0.15 \mathrm{M} \mathrm{NaCl}$, and $200 \mu \mathrm{g} / \mathrm{ml}$ BSA. Eluted proteins were precipitated with ice-cold acetone and washed once with $80 \%$ ice-cold acetone. The pellets were dissolved in $6 \mathrm{M}$ guanidine hydrochloride and incubated for 20 min at $22^{\circ} \mathrm{C}$ before dilution to a final concentration of $0.12 \mathrm{M}$ guanidine hydrochloride. The protein was allowed to renature overnight at $23^{\circ} \mathrm{C}$.

\section{Band mobility-shift assays and competition experiments}

Band mobility-shift assays were performed essentially as described (Fried and Crothers 1981, Garner and Revzin 1981), with the following modifications. LSF purified through GC123 DNA affinity chromatography (14-28 ng protein) was incubated for $10 \mathrm{~min}$ at $0^{\circ} \mathrm{C}$ in a $15 \mu \mathrm{l}$ reaction volume containing $20 \mathrm{mM}$ HEPES ( $\mathrm{pH} 7.9$ ), $100 \mathrm{mM} \mathrm{KCl}, 0.4 \mathrm{~mm} \mathrm{MgCl}_{2}, 0.2 \mathrm{~mm}$ EDTA, $17 \%$ glycerol, $2 \%$ polyvinyl alcohol, $1 \mathrm{mM}$ DTT, and $100 \mu \mathrm{g} / \mathrm{ml}$ BSA. Ten to 20 fmoles $\left(20\right.$ to $\left.30 \times 10^{3} \mathrm{cpm}\right)$ radiolabeled DNA fragment was then added, and the incubation continued for $15 \mathrm{~min}$ at $0^{\circ} \mathrm{C}$. DNA-protein complexes were separated by electrophoresis through a $5 \%$ polyacrylamide gel (60:1 acrylamide/bis-acrylamide) containing $44.5 \mathrm{~mm}$ Tris-base, $44.5 \mathrm{~mm}$ boric acid and $1 \mathrm{~mm}$ EDTA. In competition experiments, the competitor DNAs were preincubated with the protein samples for $10 \mathrm{~min}$ on ice before radiolabeled DNAs were added.
The radiolabeled and competitor DNAs, except poly[d/IC) $\cdot d(I-C)]$, were double-stranded synthetic oligonucleotides. DNAs were labeled using T4 polynucleotide kinase and $\left[\gamma^{-32}\right.$ P $]$ ATP. The sequences of the DNAs are as follows:

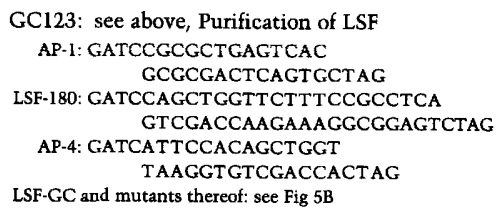

\section{Methylation interference experiments}

Methylation interference studies were performed as described previously (Siebenlist and Gilbert 1980). Eleven nanograms of duplex GC123 DNA radiolabeled at both 5' termini, was modified by dimethylsulfate and incubated with $0.8 \mu \mathrm{g} \mathrm{GC123}$ DNA affinity-purified LSF. Reaction mixtures were electrophoresed as described above for the band mobility-shift analyses. Free and complexed DNAs were visualized by autoradiography of the wet gel. Labeled DNA was excised and purified, as described (Baldwin 1988). The recovered DNA was cleaved with piperidine (Maxam and Gilbert 1980) and electrophoresed as described below for DNase I footprinting.

\section{DNase I footprinting}

DNase I footprinting probes were prepared by restricting pSEG0 plasmid DNA (Barrera-Saldana et al. 1985) at the ClaI or EcoRI sites (pBR322 nucleotides 23 and 4362), radiolabeling the 3 ' termini with $\left[\alpha^{-32}\right.$ P $\}$ NTPs using either AMV reverse transcriptase or the Klenow fragment of DNA polymerase $I$ and then digesting with HindIII. The labeled SV40 promoter-containing DNA fragments, 368 or $345 \mathrm{bp}$, respectively, were then purified from a $5 \%$ polyacrylamide gel. DNA-binding reactions were carried out in an 18- to $26-\mu \mathrm{l}$ volume with $0.5-5 \mathrm{ng}(2-20$ fmole) of the radiolabeled DNA fragment, indicated amounts of carrier DNA (poly $[\mathrm{d}(\mathrm{I}-\mathrm{C}) \cdot \mathrm{d}(\mathrm{I}-\mathrm{C})]$ ), and variable amounts of protein in a final buffer containing $25 \mathrm{mM}$ HEPES (pH 7.9), 3-4 $\mathrm{mM} \mathrm{MgCl}_{2}, 0.5 \mathrm{~mm}$ EDTA, $50 \mathrm{~mm} \mathrm{KCl}, 1 \mathrm{~mm}$ DTT, $10 \%$ glycerol, and $2 \%$ polyvinyl alcohol. Reactions were incubated for 10-15 $\mathrm{min}$ on ice or at room temperature and digested for 1 min at room temperature with $0.13-4.0 \mu \mathrm{g} / \mathrm{ml}$ DNase I (Worthington) in the presence of an additional $1.25-2.0 \mathrm{~mm}$ $\mathrm{CaCl}_{2}$ and 0.5-7.4 mM $\mathrm{MgCl}_{2}$. Guanine ladders of DNA probes were prepared as described (Maxam and Gilbert 1980). All samples were subjected to electrophoresis through an $8 \%$ polyacrylamide gel containing $7.3 \mathrm{M}$ urea, $89 \mathrm{~mm}$ Tris-base, $89 \mathrm{~mm}$ boric acid, and $2 \mathrm{mM}$ EDTA.

\section{In vitro transcription analysis}

The reconstituted transcription system included the HeLa transcription factors IIA, IIB, IIE, and IID and calf thymus RNA polymerase II. These proteins were partially purified over phosphocellulose and DEAE-cellulose columns as described (Hodo and Blatti 1977; Samuels et al. 1982, Reinberg and Roeder 1987; Reinberg et al. 1987). Transcription factors IIA (7.7 $\mu \mathrm{g})$, IIB (1.7 $\mu \mathrm{g}$ ), IIE $(0.8 \mu \mathrm{g})$, and IID $(0.9 \mu \mathrm{g})$ and RNA polymerase II (1.0 $\mu \mathrm{g})$ were combined with SV40 DNA $(16.75 \mu \mathrm{g} / \mathrm{ml})$ and pFLBH plasmid DNA $(3.25 \mu \mathrm{g} / \mathrm{ml}$ ), containing the Ad MLP (Samuels et al. 1982), in the presence of $20 \mathrm{~mm}$ HEPES ( $\mathrm{pH} 7.9$ ), $4 \mathrm{~mm}$ $\mathrm{MgCl}_{2}, 40 \mathrm{~mm} \mathrm{KCl}, 1 \mathrm{~mm}$ DTT, and $0.1 \mathrm{~mm}$ EDTA in a $16-\mu \mathrm{l}$ reaction. Reactions were preincubated at $30^{\circ} \mathrm{C}$ for $40 \mathrm{~min}$ prior 
to addition of $2 \mu \mathrm{l}$ of $10 \times$ pulse nucleotide mixture (for final concentrations of $60 \mu \mathrm{M}$ GTP, ATP, and CTP, $2 \mathrm{mM}$ creatine phosphate, $1 \mu \mathrm{M}$ UTP, and $15 \mu \mathrm{Ci}\left[\alpha^{-32}\right.$ P]UTP). Protein fractions being analyzed for transcription activity were added at the start of the $40-\mathrm{min}$ preincubation step. Incubation at $30^{\circ} \mathrm{C}$ was continued for $10 \mathrm{~min}$, followed by a 10-min chase (addition of $2 \mu \mathrm{l}$ of $10 \times$ chase nucleotide mixture, for final concentrations of $330 \mu \mathrm{M}$ GTP, ATP, and CTP and $1.0 \mathrm{mM}$ UTP/. Reactions were then terminated, and specific radiolabeled RNAs were selected by hybridization to complementary single-stranded DNAs, as described (Hansen and Sharp 1983; Kim et al. 1987). Following digestion with $\mathrm{Tl}$ RNase, resistant RNAs were resolved by electrophoresis through denaturing $5 \%$ polyacrylamide gels (29: 1 acrylamide/bis-acrylamide, $8 \mathrm{M}$ urea, $89 \mathrm{~mm}$ Tris-base, $89 \mathrm{~mm}$ boric acid, $2 \mathrm{~mm}$ EDTA). The gels were soaked in buffer to remove urea, dried, and exposed to preflashed XAR- 5 X-ray film at $-70^{\circ} \mathrm{C}$.

For competition analyses, general factors and LSF were assembled under the conditions described above, including the appropriate competitor but omitting the template DNAs. This mixture was then incubated at $0^{\circ} \mathrm{C}$ for $20 \mathrm{~min}$. Subsequently, template DNAs were added, and the reactions were preincubated at $30^{\circ} \mathrm{C}$, as described above, prior to adding nucleotides. Quantitation of the relative transcriptional stimulation was performed by scanning the autoradiographs with an LKB Ultroscan II scanning densitometer.

\section{Acknowledgments}

This paper is dedicated to the memory of Eva Paucha, an insightful scientist and a dear friend. We wish to express our appreciation to the laboratory of $\mathrm{P}$. Chambon for plasmid pSEGO, S. Batson and P. Casaz for preparation of extracts and some chromatographic fractions, D. O'Brien for technical assistance, and P. Kaplan and J. Licht for help in preparation of the figures. We also wish to acknowledge the invaluable assistance of $J$. Hirsh and P. Klein for critical reading of the manuscript, and S. Sherman for preparing the manuscript. This research was supported by the National Institutes of Health (R01-CA38038), the March of Dimes Birth Defects Foundation (1-1061), and the Whitaker Health Sciences Fund. R.S. was funded in part, by the National Institutes of Health (5T32-CA09031) and, in part, by the American Cancer Society (PF-3233). U.H. was funded, in part, by the American Cancer Society (JFRA-136).

\section{References}

Alwine, J.C. and J. Picardi. 1986. Activity of simian virus 40 late promoter elements in the absence of large $\mathrm{T}$ antigen: Evidence for repression of late gene expression. I. Virol. 60: $400-404$.

Ayer, D.E. and W.S. Dynan. 1988. Simian virus 40 major late promoter: a novel tripartite structure that includes intragenic sequences. Mol. Cell. Biol. 8: 2021-2033.

Baldwin, A.S. Jr. 1988. Methylation interference assay for analysis of DNA-protein interactions. In Current protocols in molecular biology. (ed. F.M. Ausubel, R. Brent, R.E. Kingston, D.D. Moore, J.G. Seidman, J.A. Smith, and K. Struhl), Vol. 2, Chapter 12.3. Greene Publishing John Wiley, New York.

Barrera-Saldana, H., K. Takahashi, M. Vigneron, A. Wildeman, I. Davidson, and P. Chambon. 1985. All six GC motifs of the SV40 early upstream element contribute to promoter activity in vivo and in vitro. $E M B O / .4: 3839-3849$.

Beard, P. and H. Bruggmann. 1988. A transcription factor from simian virus 40 chromosomes which activates the viral late promoter in vitro. J. Virol. 62: 4296-4302.

Bradford, M.M. 1976. A rapid and sensitive method for the quantitation of microgram quantities of protein utilizing the principle of protein-dye binding. Anal. Biochem. 72: 248254.

Brady, J., M. Radonovich, M. Vodkin, V. Natarajan, M. Thoren, G. Das, J. Janik, and N.P. Salzman. 1982. Site-specific base substitution and deletion mutations that enhance or suppress transcription of the SV40 major late RNA. Cell 31: 625-633.

Brady, J., M. Radonovich, M. Thoren, G. Das, and N.P. Salzman. 1984. Simian virus 40 major late promoter: An upstream DNA sequence required for efficient in vitro transcription. Mol. Cell. Biol. 4: 133-141.

Brady, J. and G. Khoury. 1985. Trans-activation of the simian virus 40 late transcription unit by T-antigen. Mol. Cell. Biol. 5: $1391-1399$.

Briggs, M.R., J.T. Kadonaga, S.P. Bell, and R. Tjian. 1986. Purification and biochemical characterization of the promoterspecific transcription factor, Spl. Science 234: 47-52.

Chalifour, L.E., D.O. Wirak, U. Hansen, P.M. Wassarman, and M.L. DePamphilis. 1987. cis- and trans-acting sequences required for expression of simian virus 40 genes in mouse oocytes. Genes Dev. 1: 1096-1106.

Comb, M., N. Mermod, S.E. Hyman, J. Pearlberg, M.E. Ross, and H.M. Goodman. 1988. Proteins bound at adjacent DNA elements act synergistically to regulate human proenkephalin cAMP inducible transcription. EMBO $J$. 7:37933805.

Dynan, W.S. 1986. Promoters for housekeeping genes. Trends Genet. 2: 196-197.

Ernoult-Lange, M., F. Omilli, D. O'Reilly, and E. May. 1987. Characterization of the simian virus 40 late promoter: relative importance of sequences within the 72-base-pair repeats differs before and after viral DNA replication. I. Virol. 6: $167-176$

Fried, M., and D.M. Crothers. 1981. Equilibria and kinetics of lac repressor-operator interactions by polyacrylamide gel electrophoresis. Nucleic Acids Res. 9: 6505-6525.

Fromm, M. and P. Berg. 1982. Deletion mapping of DNA regions required for SV40 early region promoter function in vivo. J. Mol. Appl. Genet. 1: 457-481.

Garner, M.M., and A. Revzin. 1981. A gel electrophoresis method for quantifying the binding of proteins to specific DNA regions: Application to components of the Escherichia coli lactose operon regulatory system. Nucleic Acids Res. 9: 3047-3060.

Gidoni, D., W.S. Dynan, and R. Tjian. 1984. Multiple specific contacts between a mammalian transcription factor and its cognate promoters. Nature 312: 409-413.

Gidoni, D., J.T. Kadonaga, H. Barrera-Saldana, K. Takahashi, P. Chambon, and R. Tjian. 1985. Bidirectional SV40 transcription mediated by tandem Spl binding interactions. Science 230: $511-517$.

Hager, D.A.. and R.R. Burgess. 1980. Elution of proteins from sodium dodecyl sulfate-polyacrylamide gels, removal of sodium dodecyl sulfate, and renaturation of enzymatic activity: Results with sigma subunit of Escherichia coli RNA polymerase, wheat germ DNA topoisomerase, and other enzymes. Anal. Biochem. 109: 76-86.

Hansen, U. and P.A. Sharp. 1983. Sequences controlling in vitro transcription of SV40 promoters. EMBO I. 2: 2293-2303.

Hartzell, S.W., B.J. Byrne, and K.N. Subramanian. 1984a. Mapping of the late promoter of simian virus 40 . Proc. Natl. Acad. Sci. 81: 23-27. 
$1984 \mathrm{~b}$. The simian virus 40 minimal origin and the 72 base-pair repeats are required simultaneously for efficient induction of late gene expression with large tumor antigen. Proc. Natl. Acad. Sci. 81: 6335-6339.

Hertz, G.Z., and J.E. Mertz. 1988. The enhancer elements and GGGCGG boxes of SV40 provide similar functions in bidirectionally promoting transcription. Virology 163: 579-590.

Ho, Y.-S., M. Lewis, and M. Rosenberg. 1982. Purification and properties of a transcriptional activator: The cII protein of phage $\lambda . J$. Biol. Chem. 257: 9128-9134.

Hodo, H.G. and S.P. Blatti. 1977. Purification using polyethylenimine precipitation and low molecular weight subunit analyses of calf thymus and wheat germ DNA-dependent RNA polymerase II. Biochemistry 16: 2334-2343.

Johnson, P.F. and S.L. McKnight. 1989. Eukaryotic transcriptional regulatory proteins. Annu. Rev. Biochem. 58: 799839.

Kadonaga, J.T. and R. Tjian. 1986. Affinity purification of sequence-specific DNA binding proteins. Proc. Natl. Acad. Sci. 83: 5889-5893.

Kadonaga, J.T., K.A. Jones, and R. Tjian. 1986. Promoter-specific activation of RNA polymerase II transcription by Spl. Trends Biochem. 11: 20-23.

Keller, J.M. and J.C. Alwine. 1985. Analysis of an activatable promoter: sequences in the simian virus 40 late promoter required for T-antigen-mediated trans activation. Mol. Cell. Biol. 5: 1859-1869.

Kim, C.H., C. Heath, A. Bertuch, and U. Hansen. 1987. Specific stimulation of simian virus 40 late transcription in vitro by a cellular factor binding the simian virus 4021 -base-pair repeat promoter element. Proc. Natl. Acad. Sci. 84: 60256029.

Laemmli, U.K. 1970. Cleavage of structural proteins during the assembly of the head of bacteriophage T4. Nature 227: 680685.

Manley, J.L., A. Fire, A. Cano, P.A. Sharp, and M.L. Gefter. 1980. DNA-dependent transcription of adenovirus genes in a soluble whole-cell extract. Proc. Natl. Acad. Sci. 77: 38553859.

Maxam, A.M, and W. Gilbert. 1980. Sequencing end-labeled DNA with base-specific chemical cleavages. Methods Enzymol. 65: 499-560.

Mermod, N., T.J. Williams, and R. Tjian. 1988. Enhancer binding factors AP-4 and AP-1 act in concert to activate SV40 late transcription in vitro. Nature 332: 557-561.

Omilli, F., M. Ernoult-Lange, J. Borde, and E. May. 1986. Sequences involved in initiation of simian virus 40 late transcription in the absence of $\mathrm{T}$ antigen. Mol. Cell. Biol. 6: $1875-1885$.

Pabo, C.O. and R.T. Sauer. 1984. Protein-DNA recognition. Annu. Rev. Biochem. 53: 293-321.

Piatak, M., P.K. Ghosh, L.C. Norkin, and S.M. Weissman. 1983. Sequences locating the $5^{\prime}$ ends of the major simian virus 40 late mRNA forms. I. Virol. 48: 503-520.

Piatak, M., K.N. Subramanian, P. Roy, and S.M. Weissman. 1981. Late messenger RNA production by viable simian virus 40 mutants with deletions in the leader region. J. Mol. Biol. 153: 589-618.

Reinberg, D. and R.G. Roeder. 1987. Factors involved in specific transcription by mammalian RNA polymerase II: Purification and functional analysis of initiation factors IIB and IIE. J. Biol. Chem. 262: 3310-3321.

Reinberg, D., M. Horikoshi, and R.G. Roeder. 1987. Factors involved in specific transcription in mammalian RNA polymerase II: Functional analysis of initiation factors IIA and IID and identification of a new factor operating at sequences downstream of the initiation site. J. Biol. Chem. 262: 33223330.

Rio, D.C., and R. Tiian. 1984. Multiple control elements involved in the initiation of SV40 late transcription. I. Mol. Appl. Genet. 2: 423-435.

Robbins, P.D., D.C. Rio, and M.R. Botchan. 1986. Transactivation of the simian virus 40 enhancer. Mol. Cell. Biol. 6: $1283-1295$.

Samuels, M., A. Fire, and P.A. Sharp. 1982. Separation and characterization of factors mediating accurate transcription by RNA polymerase II. J. Biol. Chem. 257: 14419-14427.

Siebenlist, U. and Gilbert, W. 1980. Contacts between Escherichia coli RNA polymerase and an early promoter of phage T7. Proc. Natl. Acad. Sci. 77: 122-126.

Tooze, J., ed. 1981. DNA tumor viruses: Molecular biology of tumor viruses, 2nd ed. Cold Spring Harbor Laboratory, Cold Spring Harbor, New York.

Travers, A.A. 1989. DNA conformation and protein binding. Annu. Rev. Biochem. 58: 427-452.

Vigneron, M., H.A. Barrera-Saldana, D. Baty, R.E. Everett, and P. Chambon. 1984. Effect of the 21-bp repeat upstream element on in vitro transcription from the early and late SV40 promoters. $E M B O$ I. 3: 2373-2382.

Westin, G. and W. Schaffner. 1988. A zinc-responsive factor interacts with a metal-regulated enhancer element (MRE) of the mouse metallothionein-I gene. EMBO f. 7: 3763-3770.

Wray, W., T. Boulikas, V.P. Wray, and R. Hancock. 1981. Silver staining of proteins in polyacrylamide gels. Anal. Biochem. 118: 197-203.

Xiao, J.H., I. Davidson, D. Ferrandon, R. Rosales, M. Vigneron, M. Macchi, F. Ruffenach and P. Chambon. 1987. One cellspecific and three ubiquitous nuclear proteins bind in vitro to overlapping motifs in the domain B1 of the SV40 enhancer. $E M B O$ I. 6: 3005-3013. 


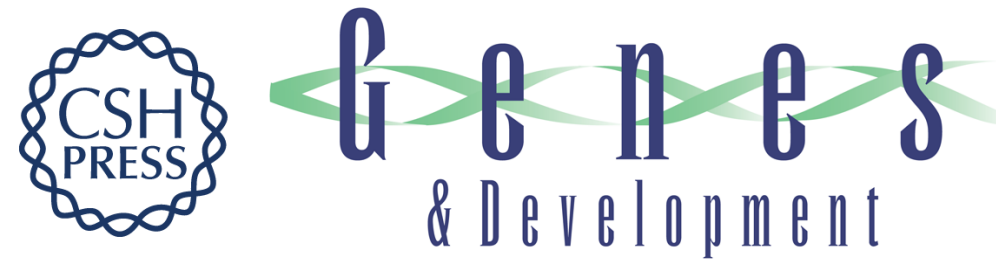

\section{Transcription factor LSF binds two variant bipartite sites within the SV40 late promoter.}

H C Huang, R Sundseth and U Hansen

Genes Dev. 1990, 4:

Access the most recent version at doi:10.1101/gad.4.2.287

References This article cites 49 articles, 22 of which can be accessed free at:

http://genesdev.cshlp.org/content/4/2/287.full.html\#ref-list-1

License

Email Alerting

Service

Receive free email alerts when new articles cite this article - sign up in the box at the top right corner of the article or click here.

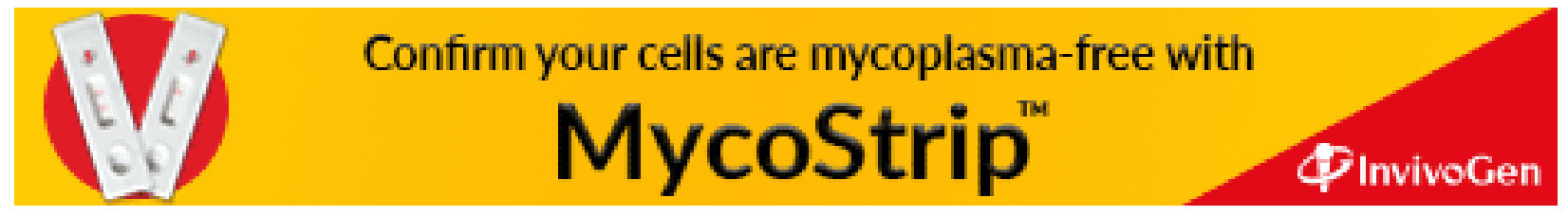

